\title{
SELECTED TRACE ELEMENT CONCENTRATIONS IN PEAT USED FOR COSMETIC PRODUCTION - A CASE STUDY FROM SOUTHERN POLAND
}

\author{
Bartłomiej GLINA ${ }^{1}$ \\ Poznan University of Life Sciences, Poznań, Poland
}

\begin{abstract}
The aim of the study was to assess the concentration of selected trace elements in organic soils used as a source to obtain a unique peat extract for cosmetics production. Peat material for laboratory analysis were collected from fen peatland located in the Prosna River Valley (Borek village). Studied peatland is managed by "Torf Corporation" company as a source of material to obtain peat extract for cosmetics production. In the collected soil samples (four soil profiles) $\mathrm{Zn}, \mathrm{Cu}$ and $\mathrm{Pb}$ concentrations were determined by using atomic absorption spectrometer SpectraAA 220 (Varian), after acid digestion. Obtained results showed that the highest concentrations of selected trace elements were recorded in the surface horizons of organic soils. This fact might be the results of Prosna river flooding or air deposition. Howevere, according to the new Polish regulations (Ordinance of the Minister for Environment 01.09.2016 - the way of conducting contamination assessment of the earth surface), the content of trace elements in the examined soils was greatly belowe the permissible limit for areas from group IV (mine lands). Thus, described soils are proper to obtain peat extract used as a component in cosmetic production.
\end{abstract}

Keywords: fen peatland, peat extraction, cosmetic industry, heavy metals

\section{INTRODUCTION}

Peatlands perform valuable functions in environment including water storage, flood mitigation, habitat and species diversity, tourism and recreations

${ }^{1}$ Corresponding author: Poznan University of Life Sciences, Department of Soil Science and Land Protection, Szydłowska st 50, 60-656 Poznań, Poland, e-mail: glina@up.poznan.pl 
opportunities [21]. Moreover, peat is a source of many active substances, humic acids in particular, which can be used for medical purpose [13]. This class of naturally occurring organic polyelectrolytes in peat is well-known for its antiviral potential [8]. In Poland the study of biologically active substances isolated from peat started in 1945 and was conducted by prof. Stanisław Tołpa in Wrocław Agricultural Academy [25]. In 1988 the licence for the production of the peat preparation on an industrial scale was sold to the Polish-American company Torf Corporation, which to this date still produce peat cosmetics. Peat extract obtain from peat soils used in cosmetic production has significant limitations in the case of trace elements concentrations, identified in European regulations $[19,20]$. The major source of trace elements in peat soils can be attributed to atmospheric deposition, supply from groundwater or as a result of anthropogenic activity [15]. Due to various patches of contamination and varied severity, permanent monitoring of peatlands quality should take place [23]. Especially when such object is used as a source of material for cosmetic productions [13].

The main objective of the study was to assess the concentration of selected trace elements $(\mathrm{Cu}, \mathrm{Zn}$ and $\mathrm{Pb})$ in organic soils according to new Polish regulations. Moreover heavy metlas content was disscused in relation to physical and physicochemical soil properties. Investrigated peat soils are used by the cosmetic industries for peat extract production which is used as a component of cosmetics.

\section{MATERIAL AND METHODS}

\subsection{Field survey and sampling}

Soil survey and sampling was carried out in October 2013 within the fen peatland located in the Borek village (opolskie voivodeship) - southern Poland (Fig. 1), in the area belonging to the Valley of Prosna river [14]. Studied peatland is supported largely by groundwater flow and partially by seasonal flooding of Prosna river. This peatland is operated by "Torf Corporation" company, as a source of peat for cosmetics and medicines production for skin care and prevention in dermo-cosmetic problems. Soil material for laboratory

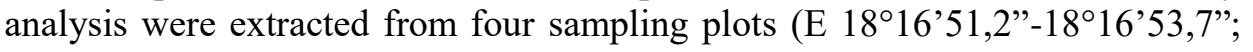
$\left.\mathrm{N} 51^{\circ} 08^{\prime} 40,1^{\prime \prime}-51^{\circ} 08^{\prime} 41,5^{\prime \prime}\right)$, using an "Instorf" peat corer. Investigated organic soils (four profiles) were classified on the basis of morphological features and physico-chemical properties, following the FAO-WRB soil classification [9] and Polish Soil Classification [18]. Representative soil samples for laboratory analysis (three replicates) were collected by genetic soil horizons 
to polyethylene bags. Separate undisturbed soil samples $\left(100 \mathrm{~cm}^{3}\right)$ for bulk density determinations were collected using Kopecky's stainless steel rings.

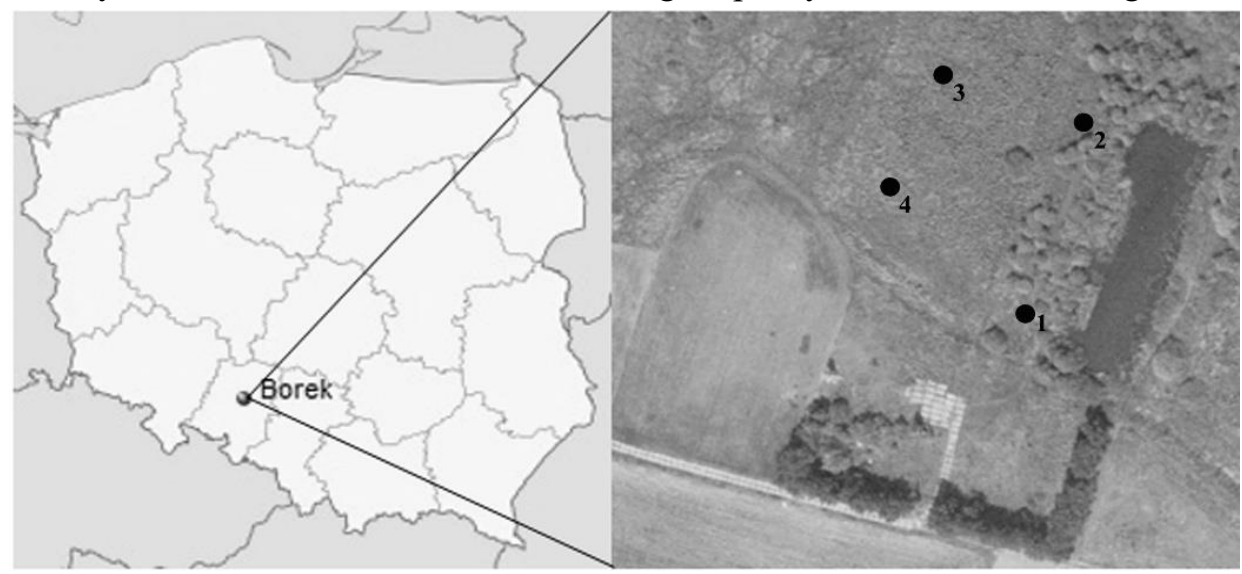

Fig 1. Location of the study organic soils profiles within the fen peatlands in Borek

\subsection{Laboratory analysis}

In the laboratory each soil sample was divided into two parts. The moist peat material was used to determine the degree of peat decomposition using the percentage fiber volume method [15] and soil $\mathrm{pH}$ potentiometrically in distilled water and in $1 \mathrm{~mol} \cdot \mathrm{dm}^{-3} \mathrm{KCl}$ at soil:solution ratio of 1:2.5 (v/v) [10]. The remaining parts of the soil samples were dried, mixed and plant remains were removed. The following properties, were determined in dry samples: ash content after placing dried samples for $5 \mathrm{~h}$ in a muffle furnace at $550^{\circ} \mathrm{C}$ [8], total organic carbon (TOC) on a CS-MAT 5500 analyzer and total nitrogen on a Büchi analyzer. The total content of selected trace elements $(\mathrm{Cu}, \mathrm{Pb}, \mathrm{Zn})$ were determined using SpectraAA 220 atomic absorption spectrometer (Varian) with background correction, after acid digestion, which was perfomed as follow: peat samples $(1 \mathrm{~g})$ were placed in the heating block and digested with $5 \mathrm{ml}$ of nitric acid (ultra pure 65\%) and $1 \mathrm{ml}$ of perchloric acid (ultra pure $70 \%$ ) at $130^{\circ} \mathrm{C}$ for 12 hours. After dilution to $50 \mathrm{ml}$ each sample was analyzed. The following analysis in each peat sample were done in triplicate. All the results were tested statisticaly (Pearson correlation) using the Statistica 12 software system (StatSoft Inc., Tulsa, OK).

\section{RESULTS AND DISCUSSION}

\subsection{Soil description and physical properties}

According to the Polish Soil Classification [18] investigated soil profiles 1 and 2 were classified as typical hemic peat soils (in Polish: gleba torfowa hemowa 
typowa), soil profile 3 - sapric-hemic peat soil (in Polish: gleba torfowa saprowa-hemowa) and profile 4 as typical sapric peat soil (in polish: gleba torfowa saprowa typowa). In the case of the FAO-WRB classification [9], studied soils belonged to Histosols reference group, with various additional preliminary and supplementray qualifiers (Tab. 1). Genetic horizons of studied soils consisted mainly of a strongly (sapric) to medium (hemic) decomposed organic material. The lowest percentage content of fiber $(<10 \%)$ was recorded in the profile 4 (Tab. 1). Obtained results of peat decomposition degree was similary to those reported by other authors for fen peatland soils in the lowland areas of Poland $[3,12]$. Ash content in studied soils contained in a wide range, between 9.11 to $72.2 \%$. The smallest amounts of mineral material admixtures were observed in endopedons, while in the surface soil horizons its content was even 5 to 7 fold higher. Increase of mineral admixture in the surface horizons might be the result of periodic flooding of Prosna river. Ash content was significantly positive correlated with bulk density values (Tab. 3). In the layers with the highest admixture of mineral particles (sand mainly) also the bulk density values were higher (Tab. 1). Similary observations were reported for peatlands periodically covered by eolian or fluvial mineral material $[14,17]$.

\subsection{Physicochemical and chemical properties}

Recorded soil $\mathrm{pH}$ values (Tab. 1) both, in $\mathrm{H}_{2} \mathrm{O}$ and $1 \mathrm{M} \mathrm{KCl}$ solutions were characteristic for minerothrophic peat soils, what clearly correspond to the ecological type of investigated peatland [22]. Total organic carbon (TOC) content was in the range $123-493 \mathrm{~g} \cdot \mathrm{kg}^{-1}$. This parameter was the lowest in the soil horizons with the highest admixture of mineral material, and 3-4 fold higher in the "pure" organic horizons (Tab. 2). The total nitrogen content (TN) was on a similar level in every of studied soil horizons, except surface horizons in profiles 3 and 4 where recorded content of TN were significantly lower (Tab. 2 ). The calculated TOC/TN ratio, widely used as an indicator for the mineralisation of organic matter $[3,4,12]$, contained in a narrow ranged from 14.4 to 20.1 . Observed low TOC/TN ratio $(<20)$ indicate temporary drying of these soils, what accelerates the mineralisation of organic matter. Relationship between organic matter mineralsation and soil moisture is commonly reported in the available literature [e.g., 4, 24]. Moreover, obtained TOC/TN ratio were similary to those reported by Kołodziejczyk also for peatland in Borek village. 
Table 1. Physical and physicochemical properites of studied soils (mean values)

\begin{tabular}{|c|c|c|c|c|c|c|}
\hline \multirow{2}{*}{$\begin{array}{c}\text { Soil } \\
\text { horizon }\end{array}$} & \multirow{2}{*}{$\begin{array}{l}\text { Depth } \\
(\mathrm{cm})\end{array}$} & \multirow{2}{*}{ Fiber $(\%)$} & \multirow{2}{*}{$\begin{array}{l}\text { Ash } \\
(\%)\end{array}$} & \multirow{2}{*}{$\begin{array}{l}\text { Bulk density } \\
\left(\mathrm{g} \cdot \mathrm{cm}^{-3}\right)\end{array}$} & \multicolumn{2}{|c|}{$\mathrm{pH}$} \\
\hline & & & & & $\mathrm{H}_{2} \mathrm{O}$ & $1 \mathrm{M} \mathrm{KCl}$ \\
\hline \multicolumn{7}{|c|}{$\begin{array}{r}\text { Profile } 1-\text { gleba torfowa hemowa typowa (PSC 2011) } \\
\text { Sapric Hemic Histosol (Dystric) (WRB 2015) }\end{array}$} \\
\hline Oa1 & $0-20$ & 6 & 37.6 & 0.34 & 5.1 & 4.8 \\
\hline $\mathrm{Oa} 2$ & $20-30$ & 4 & 17.3 & 0.22 & 5.2 & 4.8 \\
\hline Oe1 & $30-57$ & 18 & 12.2 & 0.15 & 5.3 & 4.9 \\
\hline Oa3 & $57-65$ & 10 & 10.9 & 0.12 & 5.5 & 5.0 \\
\hline Oe 2 & $65-78$ & 20 & 9.11 & 0.16 & 5.5 & 5.2 \\
\hline Oe3 & $78-100$ & 24 & 9.22 & 0.19 & 5.7 & 5.3 \\
\hline \multicolumn{7}{|c|}{$\begin{aligned} & \text { Profile } 2- \text { gleba torfowa hemowa typowa (PSC 2011) } \\
& \text { Sapric Hemic Histosol (Eutric) (WRB 2015) }\end{aligned}$} \\
\hline Oa1 & $0-20$ & 3 & 51.0 & 0.45 & 5.3 & 5.0 \\
\hline $\mathrm{Oa} 2$ & $20-27$ & 4 & 36.6 & 0.34 & 5.2 & 4.8 \\
\hline Oe1 & $27-43$ & 20 & 14.1 & 0.15 & 5.2 & 4.9 \\
\hline Oa3 & $43-50$ & 10 & 15.7 & 0.21 & 5.6 & 5.0 \\
\hline Oe2 & $50-77$ & 18 & 10.7 & 0.13 & 5.5 & 5.2 \\
\hline Oe3 & $77-100$ & 18 & 12.4 & 0.18 & 5.7 & 5.3 \\
\hline \multicolumn{7}{|c|}{$\begin{array}{c}\text { Profile } 3 \text { - gleba torfowa saprowo-hemowa typowa (PSC 2011) } \\
\text { Sapric Hemic Histosol (Eutric) (WRB 2015) }\end{array}$} \\
\hline Oa1 & $0-17$ & 6 & 50.2 & 0.36 & 5.5 & 5.3 \\
\hline $\mathrm{Oa} 2$ & $17-30$ & 8 & 36.5 & 0.24 & 5.5 & 5.1 \\
\hline Oa3 & $30-56$ & 10 & 18.5 & 0.17 & 5.2 & 4.8 \\
\hline Oa4 & $56-67$ & 10 & 19.6 & 0.22 & 5.3 & 4.9 \\
\hline Oe1 & $67-88$ & 18 & 9.60 & 0.11 & 5.6 & 5.0 \\
\hline Oe2 & $88-100$ & 18 & 12.4 & 0.19 & 5.5 & 5.2 \\
\hline \multicolumn{7}{|c|}{$\begin{aligned} \text { Profile } 4-\text { gleba torfowa saprowo-hemowa typowa (PSC 2011) } \\
\text { Sapric Hemic Histosol (Orthoeutric) (WRB 2015) }\end{aligned}$} \\
\hline Oa1 & $0-10$ & 5 & 72.2 & 0.58 & 5.9 & 5.6 \\
\hline Oa2 & $10-22$ & 8 & 71.4 & 0.60 & 5.8 & 5.1 \\
\hline Oa3 & $22-56$ & 6 & 18.1 & 0.26 & 5.7 & 5.2 \\
\hline Oa4 & $56-70$ & 8 & 19.0 & 0.17 & 5.8 & 5.3 \\
\hline Oa5 & $70-100$ & 10 & 17.2 & 0.28 & 5.9 & 5.3 \\
\hline
\end{tabular}

\subsection{Trace elements concentrations}

Organic soils from fen peatland were rather slightly contaminated with selected trace elements. The highest concentrations $\left(145-149 \mathrm{mg} \cdot \mathrm{kg}^{-1}\right)$ of copper $(\mathrm{Cu})$ were observed in the bottom soil horizons of profile 3 and 4 (Tab. 2). Similar concentration level was observed in the case of lead $(\mathrm{Pb})$, which ranged from 2.00 to $42.4 \mathrm{mg} \cdot \mathrm{kg}^{-1}$. Mean content of zinc $(\mathrm{Zn})$ in the investigated soils was significantly higher than previously described $\mathrm{Cu}$ and $\mathrm{Pb}$ amounts. Particulary 
high concentrations of zinc were found in the surface soil horizons, where they varied between 76.0 to $240 \mathrm{mg} \cdot \mathrm{kg}^{-1}$.

Table 2. Chemical properites and trace element concentrations (mean values)

\begin{tabular}{|c|c|c|c|c|c|c|c|c|}
\hline \multirow{2}{*}{$\begin{array}{c}\text { Profile } \\
\text { No. }\end{array}$} & \multirow{2}{*}{$\begin{array}{c}\text { Soil } \\
\text { horizon }\end{array}$} & \multirow{2}{*}{$\begin{array}{l}\text { Depth } \\
(\mathrm{cm})\end{array}$} & TOC & $\mathrm{TN}$ & \multirow{2}{*}{$\begin{array}{c}\text { TOC/ } \\
\text { TN }\end{array}$} & $\mathrm{Cu}$ & $\mathrm{Zn}$ & $\mathrm{Pb}$ \\
\hline & & & \multicolumn{2}{|c|}{$\mathrm{g} \cdot \mathrm{kg}^{-1}$} & & \multicolumn{3}{|c|}{$\mathrm{mg} \cdot \mathrm{kg}^{-1}$} \\
\hline \multirow{6}{*}{1} & Oa1 & $0-20$ & 301 & 20.9 & 14.4 & 20.0 & 42.4 & 116 \\
\hline & $\mathrm{Oa} 2$ & $20-30$ & 417 & 28.3 & 14.7 & 21.0 & 21.2 & 95.0 \\
\hline & Oe1 & $30-57$ & 453 & 27.2 & 16.7 & 19.0 & 7.20 & 28.0 \\
\hline & Oa3 & $57-65$ & 464 & 25.7 & 18.0 & 28.0 & 5.20 & 29.0 \\
\hline & Oe2 & $65-78$ & 486 & 26.2 & 18.6 & 19.0 & 20.8 & 42.0 \\
\hline & Oe3 & $78-100$ & 485 & 25.9 & 18.7 & 8.00 & 8.00 & 15.0 \\
\hline \multirow{6}{*}{2} & Oa1 & $0-20$ & 225 & 14.3 & 15.7 & 15.0 & 40.4 & 142 \\
\hline & Oa2 & $20-27$ & 282 & 18.2 & 15.5 & 9.00 & 23.2 & 49.0 \\
\hline & Oe1 & $27-43$ & 442 & 25.9 & 17.1 & 11.0 & 6.00 & 22.0 \\
\hline & Oa3 & $43-50$ & 440 & 22.4 & 19.6 & 19.0 & 4.40 & 24.0 \\
\hline & Oe2 & $50-77$ & 479 & 23.8 & 20.1 & 14.0 & 2.00 & 18.0 \\
\hline & Oe3 & $77-100$ & 454 & 23.4 & 19.4 & 32.0 & 8.40 & 25.0 \\
\hline \multirow{6}{*}{3} & Oa1 & $0-17$ & 209 & 13.7 & 15.2 & 13.0 & 22.4 & 89.0 \\
\hline & $\mathrm{Oa} 2$ & $17-30$ & 270 & 16.7 & 16.2 & 11.0 & 23.2 & 76.0 \\
\hline & Oa3 & $30-56$ & 408 & 22.1 & 18.4 & 25.0 & 4.80 & 35.0 \\
\hline & Oa4 & $56-67$ & 396 & 22.0 & 18.0 & 42.0 & 6.80 & 21.0 \\
\hline & Oe1 & $67-88$ & 493 & 25.8 & 19.1 & 79.0 & 7.20 & 80.0 \\
\hline & Oe2 & $88-100$ & 472 & 24.3 & 19.4 & 149 & 7.20 & 141 \\
\hline \multirow{5}{*}{4} & Oa1 & $0-10$ & 129 & 10.5 & 12.3 & 60.0 & 7.20 & 69.0 \\
\hline & $\mathrm{Oa} 2$ & $10-22$ & 123 & 8.20 & 13.8 & 231 & 10.0 & 240 \\
\hline & Oa3 & $22-56$ & 408 & 23.5 & 17.4 & 137 & 9.20 & 102 \\
\hline & $\mathrm{Oa} 4$ & $56-70$ & 416 & 24.2 & 17.2 & 102 & 2.80 & 71.0 \\
\hline & Oa5 & $70-100$ & 472 & 24.4 & 19.4 & 145 & 2.20 & 34.0 \\
\hline
\end{tabular}

Significant negative correlations with depth determined for $\mathrm{Pb}$ and $\mathrm{Zn}$ (Tab. 3), indicated that concentrations of this trace elements in studied soils is the result of atmospheric deposition. Similar observation were reported for organic soils from different area in Europe $[2,5,6]$. Also, fluvial origin of $\mathrm{Pb}$ and $\mathrm{Zn}$ is possible here, what was confirmed by statistical analysis. Observed significant positive correlation between ash content and mentioned trace element $(\mathrm{Pb}, \mathrm{Zn})$ concentrations, might indicate that periodical flooding of the Prosna river could provide substantial load of trace elements on the studied peatland. In the case of $\mathrm{Cu}$ it could be state that observed concenstrations is the results of natural acumulations (underlying mineral bedrock). Copper is an element strongly bound by organic matter resulting in low mobility of this form [11]. 
Table 3. Pearson coefficients of correlations between trace elements and soil properties $(\mathrm{n}=69)$

\begin{tabular}{|c|c|c|c|}
\hline & $\mathrm{Cu}$ & $\mathrm{Zn}$ & $\mathrm{Pb}$ \\
\hline Depth & 0.144 & $-0.600^{*}$ & $-0.442^{*}$ \\
\hline Ash & 0.239 & $0.414^{*}$ & $0.631^{*}$ \\
\hline BD & 0.356 & 0.383 & $0.653^{*}$ \\
\hline TOC & 0.155 & $0.437^{*}$ & $0.608^{*}$ \\
\hline TOC/TN & -0.047 & $-0.518^{*}$ & $-0.531^{*}$ \\
\hline $\mathrm{pH}$ in $1 \mathrm{M} \mathrm{KCl}$ & 0.307 & -0.318 & 0.010 \\
\hline
\end{tabular}

Explanation: $\mathrm{BD}$ - bulk density, * - significant at $\mathrm{p}<0.05$

According to Polish regulations on the way of conducting contamination assessment of the earth surface [1] concentrations of trace elements in studied organic soils did not exceed the permissible content for areas belong to group IV (mine lands), established at the level of $600 \mathrm{mg} \cdot \mathrm{kg}^{-1}(\mathrm{~Pb}$ and $\mathrm{Cu}$ ) and 2000 $\mathrm{mg} \cdot \mathrm{kg}^{-1}(\mathrm{Zn})$. The amounts of trace elements determined in described soils are even belowe the limit for arable areas belonging to the group II-3. At this point it is worth noting that before being released for sale, cosmetic products must meet the requirements describe in the EC regulations [20] concerning toxicological safety.

\section{CONCLUSIONS}

Based on above described results it can be assumed that Borek peatland is proper source of peat material for cosmetic products used in skin care and prevention in dermo-cosmetic problems. Determined heavy metals concentrations, close to natural concentration in soils, give guarantees to obtain peat extract with the desired quality, meets the requirements of EC regulations. Observed slightly increased concentrations of lead and zinc in the soil surface layers was the result of seasonal Prosna river flooding or atmospheric deposition.

\section{ACKNOWLEDGMENT}

The research was co-financed by the European Union as part of the European Social Fund - „Grant Plus” program, Grant No. DG-G, 4170/13.

\section{REFERENCES}

1. Decree by Ministry of Environment on the way of conducting contamination assessment of the earth surface (Item 1395, Dated 1 Sept., 2016). 
2. Ettler V., Mihaljevic M.: Distribution of trace elements in several ombrotrophic peatbogs in the Bohemians Massif. Rost. Vyr.. 45, 7 (1999) 331-334.

3. Glina B., Gajewski P., Kaczmarek Z., Owczarzak W., Rybczyński P.: Current state of peatland soils as an effect of long-term drainage preliminary results of peatland ecosystems investigation in the Grójecka Valley (central Poland). Soil Science Annual, 67, 1 (2016) 1-7.

4. Glina B., Bogacz A., Gulyás M., Zawieja B., Gajewski P., Kaczmarek Z.: The effect of long-term forestry drainage on the current state of peatland soils: A case study from the Central Sudetes (SW Poland), Mires and Peat, 18, 21 (2016) 1-11.

5. Glina B., Bogacz A.: Concentrations and pools of trace elements in organic soils in the Izera Mountains, Journal of Elementology, 18, 2 (2013) 199-209.

6. Gerdol R., Bragazza L.: Effects of altitude on element accumulation in alpine moss. Chemosphere, 64 (2006) 810-816.

7. Heiri O., Lotter A. F., Lemcke G.: Loss on ignition as a method for estimating organic and carbonate content in sediments: reproducibility and comparability of results, Journal of Paleolimnology, 25 (2001) 101-110.

8. Humus Chemistry: Genesis, Composition, Reactions, edit FJ. Stevenson, John Wiley \& Sons Ltd, New York 1994.

9. IUSS Working Group WRB.: World reference base for soil resources. International Soil Classification System for Naming Soil and Creating Legends for Soil Maps, Food and Agriculture Organization of the United Nations, Rome 2015.

10. Kabala C., Musztyfaga E., Gałka B., Labuńska D., Mańczyńska P.: Conversion of soil pH 1:2.5 KCl and 1:2.5 H2O to 1:5 H2O-conclusions for soil management, environmental monitoring and international soil databases, Polish Journal of Environmental Studies, 25 (2016) 647-653.

11. Kabata-Pendias A., Kabata-Pendias H.: Bogeochemia pierwiastków śladowych, Warszawa, Wyd PWN 1999.

12. Kalisz B., Łachacz A., Głażewski R.: Effects of peat drainage on labile organic carbon and water repellency in NE Poland. Turkish Journal of Agriculture and Forestry, 39 (2015) 20-27.

13. Kleb B., Benkovics L., Török Á., Dömsödi J.: Peat exploration for medical use. Periodic Polytechnica ser. Civil Engineering, 43, 2 (1999) 233-242.

14. Kołodziejczyk K.: Plant macroremains analysis as the basis for assessing degradation of peatlands used in agriculture. $\mathrm{PhD}$ thesis, Wrocław Univeristy of Life Sciences (2013) pp. 237.

15. Krumins J., Kuske E., Klavins M.: Major and trace element accumulation in fen peat from Elki and Viki mires in Western Latvia. Scientific Journal of 
Riga Technical University, Material Science and Applied Chemistry, 24 (2011) 71-81.

16. Lynn W.C., McKinzie W.E., Grossmann R.B.: Field laboratory test for characterization of Histosols. in: Histosols: Their Characteristic and Use, edit Stelly M, SSSA Spec. Pub, 6 Medison 1974, 10-20.

17. Margielewski W.: Torfowiska osuwiskowe polskich Karpat fliszowych jako czuly indykator zmian paleośrodowiska późnego glacjału i holocenu, Studia Limnologica et Telmatologica, 8, 1 (2014) 37-55.

18. Polish Soil Classification (Systematyka gleb Polski), Roczniki Gleboznawcze - Soil Science Annual, 62, 3 (2011) 1-193 (in Polish with English abstract).

19. Regulation (EC) No 1907/2006 of the European Parliament and of the Council of 18 December 2006 on the Registration, Evaluation, Authorisation and Restriction of Chemicals.

20. Regulation (EC) No 1223/2009 of the European Parliament and of the Council of 30 November 2009 on Cosmetics Products.

21. Schimelpfenig D. W., Cooper D. J., Chimner R. A.: Effectiveness of Ditch Blockage for Restoring Hydrologic and Soil Processes in Mountian Peatlands, Restoration Ecology, 22, 2 (2014) 257-265.

22. Sjörs H., Gunnarson U.: Calcium and $p H$ in north and central Swedish mires water, Journal of Ecology, 90 (2002) 650 - 657.

23. Strategy for Responsible Peatlands Management. edit. D. Clarke, J. Riley, International Peat Society. Jyväskylä, Finland 2010.

24. Sokołowska Z., Szajdak L., Matyka-Sarzyńska D.: Impact of the degree of secondary transformation on acid-base properties of organic compounds in mucks, Geoderma, 127, (2005) 80-90.

25. Tołpa S.: The history of the discovery and development of investigation on Totpa Torf preparation. in: Preclinical investigation of Tołpa Torf Preparation (TPP) Wrocław, edit A. Danysz, Torf Corporation (1992).

\section{KONCENTRACJA WYBRANYCH PIERWIASTKÓW ŚLADOWYCH W TORFIE WYKORZYSTYWANYM W PRZEMYŚLE KOSMETYCZNYM- STUDIUM PRZYPADKU Z POLSKI POŁUDNIOWEJ}

\section{Streszczenie}

Głównym celem badań było określenie zawartości wybranych pierwiastków śladowych w glebach organicznych torfowiska niskiego, które jest wykorzystywane jako miejsce eksploatacji torfu dla przemysłu kosmetycznego - „Torf Corporation”. Materiał analityczny do badań laboratoryjnych pobrano $\mathrm{z}$ obszaru torfowiska niskiego, znajdującego się w miejscowości Borek (województwo opolskie). W pobranych 
próbkach glebowych (cztery profile glebowe) zawartość $\mathrm{Zn}, \mathrm{Cu}$ i $\mathrm{Pb}$ oznaczono za pomocą spektrometru absorpcji atomowej SpectraAA 220 (Varian) po wcześniejszej ekstarkcji wodą królewską. Najwyższe stężenia badanych pierwiastków śladowych odnotowano w poziomach powierzchniowych badanych gleb organicznych. Fakt ten może być wynikiem okresowego zalewania torfowiska przez rzekę Prosnę lub depozycji atmosferycznej. Według polskiej normy (Rozporządzenie Ministra Środowiska 01.09.2016 - w sprawie sposobu prowadzenia oceny zanieczyszczenia powierzchni ziemi), zawartości pierwiastków śladowych w badanych glebach nie przekracza dopuszczalnych limitów dla obszarów z grupy IV (użytki kopalne). Dodatkowo kosmetyki $\mathrm{z}$ dodatkiem ektraktu torfowego przed wprowadzeniem na rynek muszą spełniać wymogi określone w regulacjach Parlamentu Europejskiego i Rady Europy dotyczących produktów kosmetycznych.

Słowa kluczowe: torfowiska niskie, eksploatacja, przemysł kosmetyczny, metale ciężkie

Editor received the manuscript: 27.06.2016 